The Journal of Society \& Media 2017, Vol. 1(1) 67 - 83

https://journal.unesa.ac.id/index.php/jsm/index

\title{
PRAKTIK PEMBELAJARAN SOSIAL PADA CO-MANAGEMENT AIR MINUM MASYARAKAT SEKITAR SUMBER AIR
}

\author{
Rachmad K. Dwi Susilo \\ Jurusan Sosiologi Universitas Muhammadiyah Malang \\ Email: rachmad_umm2004@yahoo.com
}

\begin{abstract}
Abstrak
Konflik sumber daya air minum menguatirkan sebab kondisi kelangkaan air dan nilai intrinsik air yang sudah sangat beragam. Co-management diyakini mampu mencegah konflik-konflik sosial. Sayangnya, co-management masih menyisakan kelemahan jaringan sosial aktor yang belum kuat. Oleh karena itu, diperlukan pembelajaran sosial (social learning).Tujuan penelitian ini yaitu menggambarkan praktik co-management air minum pada masyarakat sekitar sumber air. Selain itu, menggambarkan pembelajaran sosial dipraktekkan pada comanagement air minum pada masyarakat sekitar sumber air itu.Metode penelitian yang digunakan yakni metode kualitatif dengan pendekatan PAR (Participatory Action Research). Hasil penelitian yang ditemukan yakni co-management sudah berjalan bertahun-tahun yang dimotori oleh organisasi berbasis komunitas yakni HIPPAM (Himpunan Penduduk Pemakai Air Minum) yang beroperasi di dusun-dusun. Organisasi ini terintegrasi dengan lembaga desa dan organisasi di luar desa.Sementara itu, pembelajaran sosial sudah berkembang sejak organisasi ini berdiri dengan melepaskan diri dari pengelolaan air minum dari PDAM.Masingmasing-masing HIPPAM dusun mengembangkan pembelajaran sosial dimana bertujuan memenuhi kebutuhan air minum. Dilapangan masih ditemukan kelemahan dari pembelajaran sosial mengingat pengelolaan air minum dusun belum terintegrasi pada level desa. Untuk kepentingan ini dilakukan FGD HIPPAM dusun, Saresehan dan FGD semua aktor comanagement.Langkah-langkah ini mampu menggambarkan co-management berbasis pembelajaran sosial.Selain itu, membangun penyadaran, persamaan persepsi dan penyebaran pengetahuan antaraktor.
\end{abstract}

Kata kunci: co-management, pembelajaran sosial, konflik sumber daya air

\begin{abstract}
The conflict of management of drinking water resources were worried because of scarcity condition and multiple intrinsic value of water. Co-management was believed to able to prevent the social conflict. Unfortunately, co-management still leaved over weak social network. Therefore, the need is social learning. The purpose of research is to describe co-management of drinking water in community surrounding water sources. Besides, to describe social learning that practices in co-management. The method of the research that used is qualitative research methods with PAR (Participatory Action Research) approach. The result of research that comanagement has practiced many years that motorized community based organization namely HIPPAM (Himpunan Penduduk Pemakai Air Minum /The Association of Drinking Water Used Population) which operates in villages. These organizations integrated to another village and outside organization. Meanwhile, social learning developed since the organization was founded by separating to local drinking water corporation. Each HIPPAMs in village has been developing social learning that its purpose is to fulfill drinking water need. In the field it was still founded weakness of social learning namely co-management has integrated yet in the village bond. For this interest we conducted FGD of village's HIPPAM, Saresehan The village of co-management actors and FGD of all actors of co-management. The ways succeeded to describe social learning based co-management, also building awareness, united perception and spread knowledge among actors.
\end{abstract}

Keywords: co-management, social learning, water resources conflict 


\section{Latar Belakang}

Diskusi tentang pengelolaan dan pemenuhan kebutuhan air mendesak dilakukan mengingat kita sudah memasuki era kelangkaan air. Kelangkaan dialami tidak hanya oleh masyarakat dimana berlokasi jauh dari mata air, tetapi masyarakat yang tinggal di sekitar sumber air juga sudah mulai merasakan persoalan itu. Pada konteks lokal sekalipun Kota Batu dikatakan sebagai kota yang kaya dengan mata air, tetapi masih ditemukan masyarakat desa yang mengalami kesulitan untuk memenuhi kebutuhan air bersih. Belum lagi resiko sosial yang mengancam akan lahirnya konflik-konflik sosial.

Resiko sosial masyarakat sumber air yakni akan menghadapi persoalan-persoalan dilematis. Secara umum, kelangkaan air sudah terjadi dimana-mana dikarenakan volume air kini kurang mampu menyuplai kebutuhan penduduk yang semakin padat. Sementara itu, alam dan lingkungan yang semakin tidak terurus turut memperparah kelangkaan ini. Debit air menurun seiring dengan kurang terpeliharanya lingkungan.

Kemudian, yang sering menjadi persoalan yakni pengelolaan air dimana kurang mengakomodir kepentingan semua stakeholders. Pemerintah selalu merasa bahwa dirinya yang memiliki otoritas untuk pendayagunaan air. Ketika peran ini berbenturan dengan masyarakat, maka rentan memunculkan konflik sosial, terlebih dewasa ini, air memiliki nilai intrinsik, tidak hanya terkait pada satu nilai. Air memiliki nilai sosial, ekonomi, religius, kultural dan lingkungan (Sanim, Bunasar, 2011: 6).

Tidak heran, di Kota Batu, tercatat kasus-kasus terkait pengelolaan air minum, seperti: konflik Warga Desa Pandanrejo dengan PDAM Kota Batu, disebabkan pelayanan PDAM di satu dusun tidak maksimal, dimana akhirnya mendirikan HIPPAM (Himpunan Penduduk Pemakai Air Minum). Sementara itu, Warga Ngaglik yang menjadi pelanggan PDAM Kota Batu yang dirasakan oleh masyarakat mahal. Kemudian, yang masih terjadi sampai sekarang yaitu konflik Pemerintah Kota Batu dengan warga tiga desa pengguna sumber air Gemulo, terkait rencana dibangunnya Hotel Resort The Rayja di sekitar mata air gemulo.

Pembangunan ini dikeluhkan masyarakat, sebab ketergantungan atas air yang menjadi tumpuan masyarakat baik untuk pemenuhan kebutuhan pertanian maupun air minum. Menariknya, sekalipun 3 desa pengguna air sudah melontarkan keberatan dan menggalang dukungan penolakan, tetapi tetap saja pembangunan hotel berjalan.

Di Indonesia, konflik sosial memperebutkan akes air semakin marak. Sobirin (2010) menjelaskan tentang kemunculan konflik masyarakat di Pegunungan Kendeng, Kabupaten Pati 
menolak berdirinya PT Semen Gresik di daerah itu. Faktor pendorong masyarakat lokal untuk melakukan penolakan disebabkan ada kekuatiran akan terjadinya kerusakan sumber mata air. Mengingat, seperti yang terjadi di Kota Batu, dimana ketergantungan akan keberadaan sumber mata air sangat tinggi. Bisa dipastikan, konflik akibat kelangkaan sumber daya air akan semakin keras. Hal ini tidak lepas dari semakin langkanya air dan jumlah penduduk yang kian meningkat.Selain itu, masyarakat juga sudah semakin cerdas seiring iklim demokrasi yang sudah merambah isu-isu lingkungan.

Pada konteks inilah, co-management mampu mengurangi potensi-potensi konflik sosial tersebut, sebab ia merupakan kolaborasi semua aktor atau stakeholders, baik dari komunitas sekitar, pemerintah maupun pelaku bisnis (swasta). Semua pihak sama-sama menyadari joint management ini. Latar belakang yang tidak sama, baik dari agen negara, pelaku bisnis maupun masyarakat dekat sumber daya alam akan mengharuskan pembagian (sharing) antara negara dengan masyarakat lokal, baik itu menyangkut pembagian kekuasaan, tugas, resiko, tanggung jawab, keberhasilan dan kegagalan.

Co-management memilikiunsur-unsur pokok, sebagai berikut: 1) Pihak-pihak yang terlibat, tidak hanya satu individu atau kelompok, tetapi lebih dari satu dengan beragam latar belakang kepentingan untuk kolaborasi. 2) Pengambilan keputusan, pembagian hasil danmenanggung resiko bersama-sama. 3) Sifat hubungan pihak-pihak yang terlibat sangat bervariasi antara hubungan formal dengan hubungan informal.

Kelebihan co-management dibanding model pengelolaan berbasis komunitas dan pengelolaan berbasis negara.Kelemahan pengelolaan berbasis komunitas yakni keterbatasan kapital fisik, kapital sosial dan manusia.Selain itu, lemahnya dukungan elit dan pemerintah lokal.Sementara itu, pengelolaan berbasis negara karena gagal merefleksikan realitas-realitas lokal pada komunitas yang menjadi target.Kasus di Danau Nairasha, Kenya bahkan pendekatan kedua ini menghasilkan kerusakan lingkungan yang parah (Isyaku, Usman, Murtala Chindo dan Mukhtar Ibrahim, 2011).

Keberhasilan co-managementakan menghasilkan pertukaran sumber daya, pengurangan biaya dan resiko, mengatasi ketidakpercayaan, inefisiensi dan pencegahan konflik (Sekhar, Udaya Nagothu, 2006). Selain itu, pada konteks pemgelolaan sumber daya mampu menciptakan tiga hal, yaitu pertama, meningkatkan kesadaran masyarakat tentang pentingnya keberlanjutan sumber daya alam yang menunjang kehidupan. Kedua, meningkatnya partisipasi masyarakat dalam mengelola sumber daya secara terpadu. Ketiga, meningkatnya kesejahteraan masyarakat dengan tetap menjamin adanya kelestarian dan keberlanjutan ekologis (Hanif, Hasrul, 2008) 
Permasalahan yang masih terjadi yaitu masih ditemukan praktik co-management itu dengan aktor-aktor pasif. Relasi sosial aktor kurang berjalan maksimal dikarenakan koordinasi belum berjalan rutin, sehingga jaringan sosial belum menghasilkan peran-peran strategis. Salah satu sebab karena kebijakan pengelolaan sumber daya alam dimana belum meninggalkan karakter sentralistik. Artinya, sekalipun pengelolaan sudah mengakomodasi keberadaan aktor luar negara secara luas, tetapi praktiknya belum berjalan baik.

Hemat penulis diperlukan cara untuk mendorong berfungsinya aktor-aktor tersebut, dalam konteks ini pembelajaran sosial akan mampu mengurangi kelemahan-kelemahan tersebut. Dikarenakan, pembelajaran sosial seperti dinyatakan Bandura sebagai proses pembelajaran individu yang dipicu oleh konteks sosial seperti orang lain, situasi sosial dan lembaga. Dari proses ini akan muncul efek dari pengamatan dan mengimitasi perilaku lain atau refleksi kognitif kejadian dan pengalaman sosial (Siebenhuner, Bernd \& Heinrich Harald, 2010).

Dalam pembelajaran ini individu mendapat pengetahuan maupun pembelajaran dari berbagai sumber, baik dengan cara mengamati, belajar langsung maupun belajar kepada orang lain. Segala objek bisa dimanfaatkan sebagai bahan-bahan pembelajaran sosial.Hanya yang menjadi syarat penting bahwa pembelajaran tidak bersifat individual, melainkan harus dibentuk bersama-sama.

Pembelajaran sosial berperan sangat penting dalam menggerakkan co-management dan mendorong pengelolaan co-management secara adaptif, tata kelola reflektif dan managemen transisi (Mulder, Biesiot \& Smith dalam Siebenhuner, Bernd \& Heinrich Harald, 2010). Mc Fadden, Loraine, Sally Priest \& Colin Green, 2008, menyatakan co-management adaptif yaitu sebuah proses dimana kerangka institusional dan pengetahuan ekologis direvisi melalui proses belajar sambil bertindak dinamis, terus menerus dan diorganisasi sendiri. Dari latar belakang di atas, penelitian ini bertujuan menggambarkan co-management air minum masyarakat sekitar sumber air selama ini. Kemudian, menjelaskan bagaimana pembelajaran sosial dipraktikkan pada co-management air minum masyarakat sekitar sumber air?

\section{Metode Penelitian}

Metode penelitian yang digunakan pada penelitian ini yaitu metode penelitian kualitatif dengan pendekatan PAR (Participatory Action Research), dimana tujuan penelitian ini mengembangkan model co-management berbasis pembelajaran sosial. Pada tahap I akan dideskripsikan model co-management yang dipraktekkan selama ini, terutama menyangkut hubungan, sumbangan, peran aktor-aktor dan stakeholders pada pengelolaan air minum. 
Dengan teknik pengumpulan data meliputi, wawancara, observasi, studi dokumen dan FGD (Focus Group Discussion) tergambarkan bentuk/struktur co-management selama ini.

Untuk pembuatan model di atas perlu digali konsep co-management seperti tergambarkan dalam data-data, terkait dengan :

1. Gambaran co-management selama ini

2. Tugas dan kewajiban aktor/ stakeholders yang terlibat

3. Bentuk pertukaran sumber daya

4. Pembagian (sharing) resiko \& tanggung jawab antarstakeholder

5. Regulasi yang mengatur struktur hubungan antaraktor dan antarstakeholders

Dengan pendekatan PAR (Participatory Action Research) model co-management dikembangkan melalui metode refleksi dan perencanaan (seperti gambar 1.1). Adapun subjek penelitian yaitu semua aktor yang terlibat pada co-management, seperti pada level desa, meliputi: Kepala Desa, Sekretaris desa, Ketua BPD, Ketua LPMD dan Ketua-Ketua HIPPAM Dusun (Dusun Pandan, Dusun Kajar, Dusun Dadapan dan Dusun Ngujung). Sementara itu, dari level kota terdapat Dinas PU Pengairan \& Binamarga, Kantor Lingkungan Hidup, BAPPEDA, Dinas Cipta Karya dan Tata Ruang, NGO (Non Governmental Organization) yang bergerak pada isu lingkungan, PDAM Kota Batu, Desa yang diambil sumber air dan desa yang mengambil air dari sumber air yang ada di Desa Pandanrejo. Sedangkan, teknik pengumpulan data meliputi wawancara mendalam, observasi dan FGD, baik pelaku co-management di level dusun maupun yang ada di level desa. 


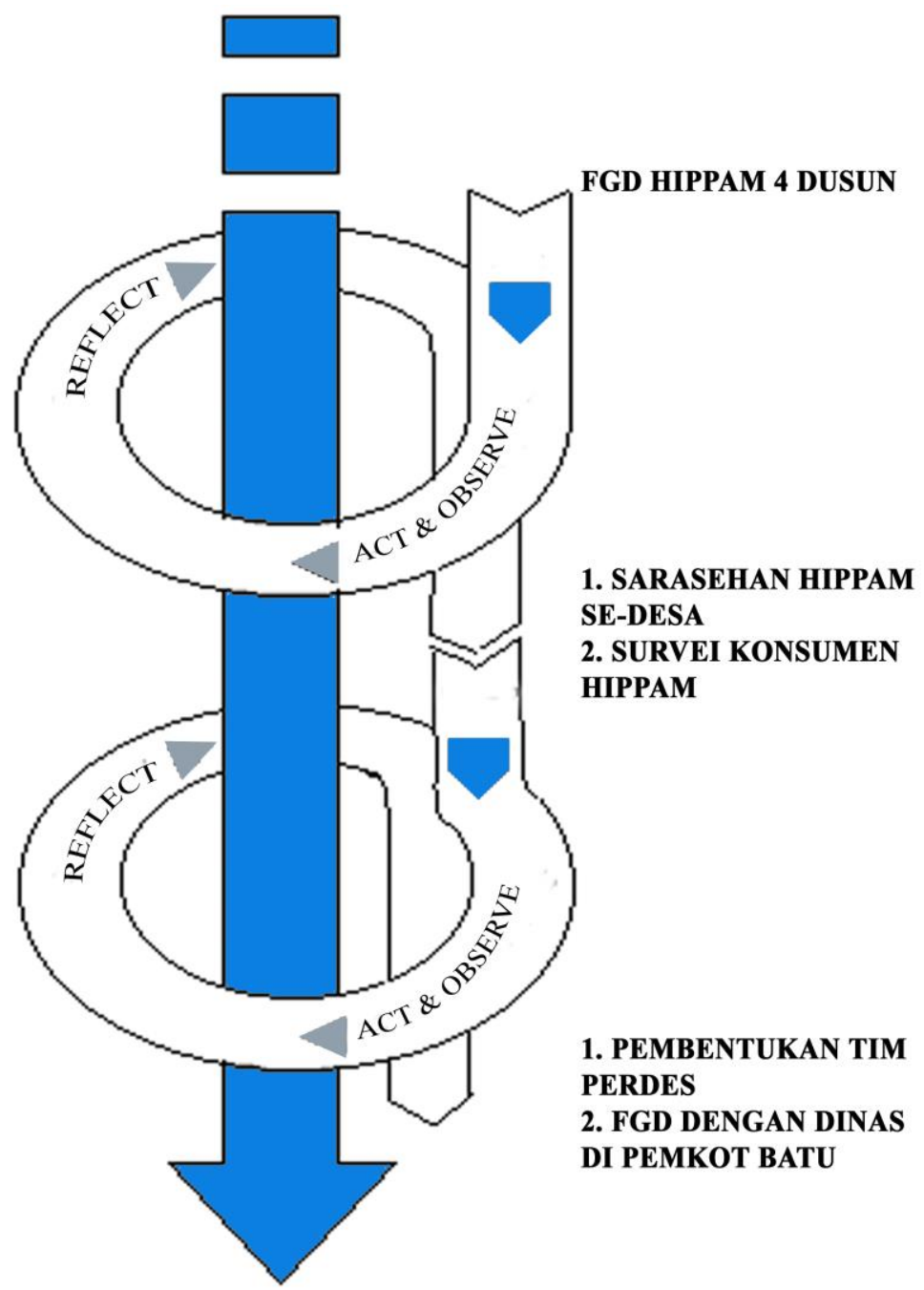

Gambar 1.Siklus Penelitian

Dengan cogenerative dialogue peneliti akan mengembangkan co-management berbasis pembelajaran sosial, dimana model ini tidak hanya dibangun oleh masyarakat lokal sebagai insiders atau hanya dibangun peneliti sebagai outsiders, tetapi dilakukan bersama-sama sesuai peran dan fungsi masing-masing (Elden, Max \& Morten Levin dalam White, Foote William (editor), 1991:134-135).

\section{Pembahasan}

\section{a. Co-management dan Pemenuhan Kebutuhan Air Minum}

Sekalipun secara sederhana co-management diartikan sebagai pengelolaan bersama, tetapi konteks co-management terkait pengelolaan sumber daya alam, terutama sumber daya-sumber daya kolektif, baik pada pemilikan maupun pemanfaatan, seperti padang luas, hutan, pemeliharan/perlindungan binatang-binatang/tumbuh-tumbuhan dan sumber daya air minum. 
Urgensi pemilihan co-management karena ia mampu mendamaikan banyak perbedaan, diantaranya: Pertama, perbedaan kepentingan, seperti pada pengelolaan air minum, pemerintah sering mendasarkan aturan-aturan formal positivistik dimana kurang memperhatikan keragaman dan penghormatan kepentingan-kepentingan pihak lain, terutama masyarakat sekitar sumber daya. Ketika orientasi pebisnis yaitu mencari keuntungan mengundang keberatan banyak pihak, sering pemerintah sebagai pemberi izin, tidak mendengar masukan-masukan dari masyarakat.

Kedua, perbedaan pengetahuan, yaitu pemanfaatan pengetahuan ilmiah sering berbenturan dengan pengetahuan tradisional karena logika dan kepentingan yang tidak sama. Perbedaan ruang yang turut menyebabkan perbedaan cara berfikir tersebut. Pada saat masing-masing pihak tidak bisa menerima pendapat atau masukan-masukan dari pihak lain, maka rentan melahirkan konflik. Dengan demikian co-management mampu mencegah dan meminimalisir potensi-potensi konflik.Co-management merupakan bentuk mekanisme demokratis yang terjadi pada pengelolaan sumber daya alam karena hak-hak dan kewajiban semua pihak diakui. Sementara itu, model co-management yang ditemukan peneliti di Desa Pandanrejo, Kota Batu seperti tergambarkan dalam bagan berikut,

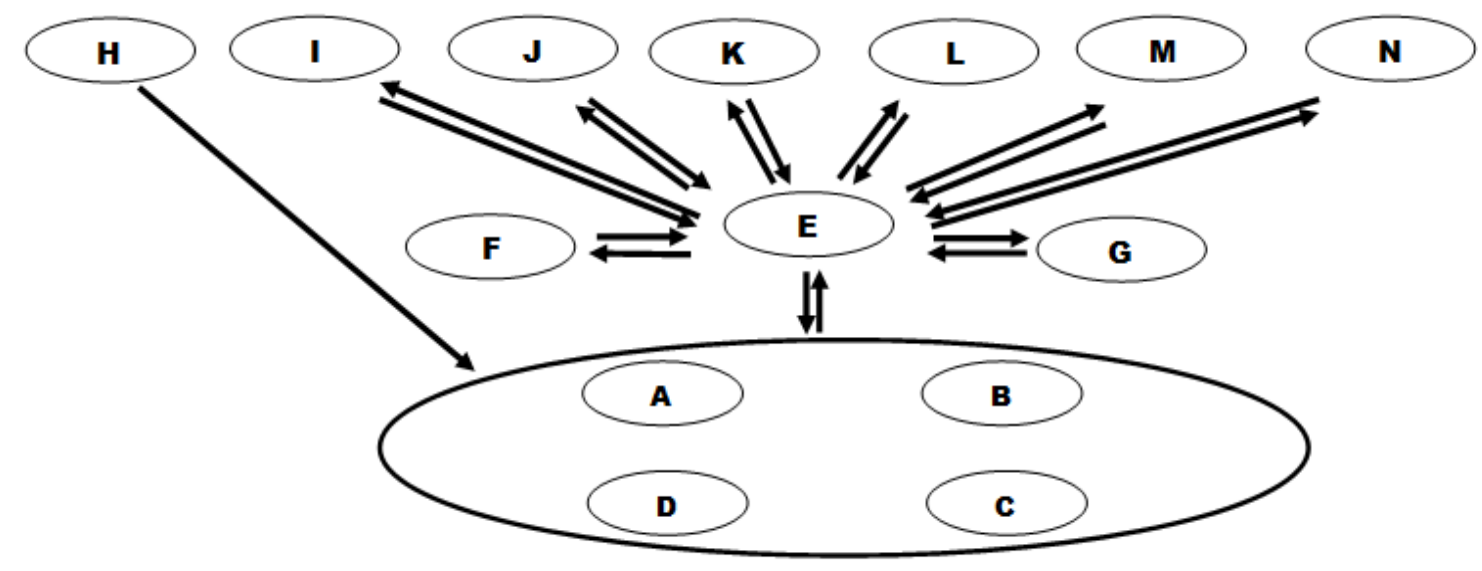

MODEL CO-MANAGEMENT BERBASIS PEMBELAJARAN SOSIAL

KETERANGAN;

$\begin{array}{llll} & \text { Pembelajaran Sosial (Social Learning) } & & \\ \text { A.B.CD } & =\text { HIPPAM DUSUN } & \text { J } & \text { = BAPPEDA (Badan Perencanaan Pembangunan } \\ \text { E } & =\text { Pemerintah Desa (Kepala Desa,LPMD, } & \text { Daerah) } & \\ \text { Perangkat } & & \text { K } & \text { = Dinas Pengairan dan Bina Marga } \\ \text { F } & =\text { BPD (Badan Permusyawaratan Desa) } & \text { L } & \text { = Dinas Cipta Karya \& Tata Ruang } \\ \text { G } & =\text { KelompokTani } & \text { M } & \text { = Desa Yang Sumber Air Diambil } \\ \text { H } & =\text { LSM Lingkungan } & \text { N } & \text { = Desa Yang Mengambil Air Minum } \\ \text { I } & =\text { KLH(Kantor Lingkungan Hidup) } & & \end{array}$

Gambar 2. Model Co-management di Desa Pandanrejo

Dari gambar di atas, kita bisa menjelaskan co-management terjadi karena adanya aktoraktor yang terlibat, dimana bukan satu individu melainkan kelompok-kelompok yang berbeda 
latar belakang. Latar belakang aktor bisa dibagi menjadi dua kelompok, yakni aktor pada level desa dan aktor pada level supra desa. Kemudian, yang juga berperan penting yaitu variasi hubungan antara aktor, baik hubungan formal maupun hubungan informal. Hubungan formal misalnya antara dinas-dinas pemerintah. Sementara itu, hubungan informal misalnya, antara aktor-aktor pada level desa. Seperti, hubungan informal antara kepala dusun dengan Ketua HIPPAM. Sementara itu, hubungan antaraktor belum terlihat dinamis. Dari gambar bisa pula dilihat tidak ada hubungan antarHIPPAM. Hal ini berarti bahwa pengelolaan HIPPAM dusun berjalan sendiri-sendiri, seakan tidak ada kepentingan sebagai sesama warga desa. Selain itu koordinasi belum kuat atau belum saling belajar satu dengan lain.

Dengan demikian bisa dikatakan yang menjadi kelemahan yaitu co-management dengan koordinasi minim. Hal ini disebabkan tidak adanya lembaga khusus yang mengatur aktor-aktor. Dalam co-management belum ada organisasi penghubung (bridging organization) yang mengatur arah dan gerak co-management itu. Sebenarnya organisasi semacam ini berperan penting untuk mengatur hubungan antaraktor, mengatasi persoalan bersama, mengkombinasikan semua pengetahuan dan membangun dukungan semua sumber daya (Per Olsson, Carl Folke, Victor Galaz, Thomas Hahn dan Lisen Schutz, 2007).

Selain itu, faktor yang penting pula tidak ada legalitas yang menyerahkan sepenuhnya pegelolaan air minum kepada pelaku-pelaku yang bertempat tinggal di sekitar sumber daya alam menunjukkan dukungan pemerintah yang masih lemah. Hal ini membenarkan tesis Mc Conney, Pomeroy, Mahon, 2003 yang menyatakan bahwa terdapat 3 bentuk dari comanagement itu, yakni Consultative co-management, collaborative dan delegated comanagement.

Jika pada model consultative dan collaborativeco-management kewenangan masyarakat pada pengelolaan sumber daya alam masih dibayang-bayangi kekuasaan negara, tetapi pada delegated co-management kemitraan lebih kuat. Baik pemerintah maupun komunitas sama-sama sebagai pengambil kebijakan. Beberapa kalangan menyamakan konsep ini dengan cooperative co-management lebih menunjuk Stakeholders di luar negara diserahi kekuasaan untuk mengambil keputusan penuh. Tipe ini menyatakan bahwa komunitas memegang kendali penuh dalam managemen.

\section{b. Praktik Pembelajaran Sosial dalam Co-Management Air Minum Desa}

Pembelajan sosial tidak dipahami sebagai model pembelajaran seperti dipraktikkan di dalam ruang kelas, tetapi pembelajaran ini berproses di kelompok-kelompok masyarakat.Dimana tidak memandang status atau kedudukan, semua aktor terlibat pada pembelajaran bersama. Pembelajaran merupakan proses sosial dimana berkembang 
pengetahuan, pemahaman dan kesadaran baru berasosiasi dengan interaksi personal dari lingkungan pembelajaran. Bisa dikatakan materi pembelajaran meliputi kepentingan, pengetahuan, ketrampilan dan kapabilitas.

Goldstein menjelaskan fokus pembelajaran sosial pada aspek kognitif sebagaimana aspek yang terkait dengan nilai. Pemahaman ini hampir sama dengan pengertian pembelajaran secara umum yaitu suatu proses dimana sebuah aktivitas muncul atau dirubah lewat cara menanggapi situasi. Penyediaan perubahan tidak dapat disebut belajar apabila disebabkan oleh pertumbuhan atau keadaan sementara seseorang.Kemudian terpenting, perubahan kegiatan belajar mencakup aspek pengetahuan (kognitif), kecakapan dan tingkah laku (Janawi, 2013).

Pembelajaran sosial bisa berjalan dengan sendirinya pada sebuah komunitas yang memiliki sistem pengetahuan lokal yang kental. Seperti bisa digambarkan dari temuan-temuan lapangan bahwa pembelajaran sosial sudah ada sejak pelaku-pelaku co-management berkeinginan mengelola air minum sendiri. Keinginan dan semangat tersebut teruji ketika menata organisasi HIPPAM pada level dusun-dusun. Pengetahuan maupun pengalaman penataan air, terutama terkait pipanisasi dipelajari sendiri. Upaya mencari bantuan maupun hutang untuk organisasi juga dicari sendiri. Demikian juga ketika menemui persoalanpersoalan di lapangan juga diselesaikan sendiri. Bisa dikatakan dengan kalimat yang lain, bahwa awal dari pembelajaran sosial yaitu keberanian Pemerintah Desa Pandanrejo untuk menyetujui berdirinya HIPPAM di desa tersebut dengan melepaskan diri sebagai pelanggan PDAM Kota Batu. Keinginan Kepala Desa waktu itu agar keuangan pada pengelolaan air ini kembali ke masyarakat. Di samping tarif air minum yang mahal dan pelayanan PDAM yang tidak memuaskan. Beberapa praktik pembelajaran sosial yang diinisiasi masyarakat, sebagai berikut,

\section{HIPPAM Dusun Kajar}

Pengurus sudah mampu mencari pengetahuan sebanyak-banyaknya demi mengatasi pemenuhan kebutuhan air bersih.Selain itu, pengurus HIPPAM juga sudah mampu melobi ahli yang memiliki ketrampilan pengelolaan air lebih.Ahli tersebut diminta membantu mengatasi masalah-masalah yang dihadapi HIPPAM.Selain itu, HIPPAM Dusun Kajar, sudah memiliki pemikiran untuk menyelesaikan masalah distribusi air yang rentan konflik dengan HIPPAM Dusun Pandan.Selama ini tandon yang digunakan bersama antara HIPPAM Dusun Kajar dengan HIPPAM Dusun Pandan sering membuat hubungan keduanya kurang baik. Ketika air yang diterima Dusun Pandan kurang, yang menjadi objek kecurigaan HIPPAM Dusun Kajar, demikian kondisi sebaliknya. Agar lepas dari kondisi seperti ini, baik HIPPAM Dusun Kajar maupun Dusun Pandan mengundang teknisi dari PDAM untuk mengatur agar air merata untuk 
kedua dusun. Sementara itu, HIPPAM Dusun Kajar sudah memiliki kemampuan dan kreativitas untuk menggali sumber-sumber produktif, seperti : menggali bantuan dari luar yaitu Sekolah Selamat Pagi yang berlokasi di Dusun ini.

\section{HIPPAM Dusun Pandan}

Untuk pencapaian tujuan pemenuhan kebutuhan air, masyarakat sudah bisa memikirkan sendiri, mencari pengetahuan sebanyak-banyaknya dan mengambil keputusan tentang langkah-langkah yang mereka bisa tempuh. Misalnya, ketika air yang dirasakan oleh Dusun Pandan, semakin kurang memenuhi kebutuhan masyarakat, sementara mereka mengecek bahwa pasokan air cukup, maka perlu menghubungi orang yang ahli untuk memecahkan masalah mereka.

\section{HIPPAM Dusun Dadapan}

Sedangkan pada HIPPAM Dusun Dadapan, pembelajaran sosial terlihat pada keberanian warga untuk lepas dari PDAM yang tidak memberikan pelayanan yang baik. Ketua HIPPAM yang masih menjabat sebagai Ketua HIPPAM Desa Pandanrejo membentuk panitia di level dusun.Kemudian keorganisasian dibangun antara penitia dengan konsumen.Ia berkomitmen agar hutang dari HIPPAM terbayarkan. Menariknya mekanisme komplain bagi konsumen sudah diatur secara baik.Ketua HIPPAM tidak segan-segan untuk menerima masukan dari pelanggan, sekalipun kadang ditandai pertengkaran.

Sekalipun berusia paling muda, HIPPAM Dusun Dadapan sudah mampu memenuhi kebutuhan air minum sendiri.Hutang dimanfaatkan untuk modal mengerakkan HIPPAM, berangsur-angsur bisa dikembalikan.Sekalipun belum semua anggota HIPPAM membayar.Bisa disimpulkan bahwa semangat untuk mengelola air secara mandiri sudah dimiliki dusun ini.Sekalipun baik pengurus maupun tokoh masyarakat belum menggagapnya sebagai sesuatu yang ideal.

\section{HIPPAM Dusun Ngujung}

Pembelajaran sosial yang positif dari dusun ini yakni keinginan kuat pengurus untuk mendirikan HIPPAM, lebih dahulu dibanding HIPPAM-HIPPAM lain. Pengurus mencari sumber air sendiri dari Desa Bumiaji yang bersebelahan dengan Desa Pandanrejo.Seperti dinyatakan oleh Sekretaris Desa, kemunculan HIPPAM ini yang mengambil air dari Desa Bumiaji juga memberikan kemanfaatan sosial. Pada saat pendiri HIPPAM Ngujung meminta air dari pemilik tegalan yaitu Pak Sakeh (Desa Bumiaji), ada syaratnya, yaitu diberikan pesanpesan bahwa Pemuda Dusun Ngujung dan Dusun Pandan tidak boleh berkelahi dengan Pemuda Dusun Binangun (Bumiaji). Ternyata bentuk kecerdasan lokal (local genuine) semacam ini berjalan efektif, terbukti sampai sekarang tidak ada perkelahian antar kampung. 
Pembelajaran sosial pada HIPPAM Dusun Ngujung, yaitu kesungguhan dalam mengelola HIPPAM ditunjukkan oleh kerja sekretaris yang meluangkan waktu untuk melayani pelanggan.Jika ada pengaduan langsung ditanggapi segera. Jika ada instalasi yang rusak maka langsung diperbaiki oleh tim teknis. Pada kasus pengaduan pelanggan terkait tidak lancarnya air, sekretaris langsung meminta kepada pelanggan untuk mengajak Ketua RT untuk datang.Langkah ini dilakukan mengingat, selama ini ada Ketua RT yang tidak menyerahkan retribusi konsumen ke pengurus.Ternyata sekretaris langsung menghubungkan dengan tidak terbayarkannya rekening pelanggan.

Keadaan yang sama ketika potensi konflik terjadi antara Dusun Ngujung dengan Desa Bumiaji, gara-gara pipa air putus. Sekalipun awalnya, HIPPAM Dusun Ngujung mencurigai pelaku dari Desa Bumiaji, tetapi akhirnya bisa dilokalisir dan diselesaikan dengan baik sehingga tidak terjadi konflik sosial. Hanya saja yang masih menjadi masalah bahwa pengorganisasian HIPPAM ini belum maju, sebagian besar kerja organisasi banyak berkutat pada persoalan tunggakan yang ditanggung konsumen dan Ketua RT. Hanya saja ketika diajak FGD, RT-RT yang "bermasalah” tidak datang, sehingga untuk sementara peneliti belum bisa menganalisis dan mendiagnosa.

Peran atau posisi pembelajaran sosial lebih banyak memfasilitasi para pelaku comanagement untuk melakukan sharing antara satu dengan lain. Pembelajaran sosial dibentuk ketika aktor-aktor mengamati kelompok lain dan karena ada pengaruh-pengaruh situasional. Selain itu, bagian yang penting yakni berfungsinya jaringan sosial. Sekalipun, relasi sudah ada, tetapi tidak adanya koordinasi sering menjadi sebab jaringan sosial kurang berfungsi. Bentukbentuk pertukaran yang seharusnya membuat pengelolaan kolektif ini berjalan baik menjadi tidak berjalan. Untuk mengaktifkan ini diperlukan pembelajaran sosial dimana menyadarkan semua pihak untuk saling belajar, saling bergantung dan memahami persepsi masing-masing. Dengan demikian menghasilkan formula pengelolaan air dari banyak pihak. Beberapa kegiatan yang ditujukan untuk pembelajaran sosial, sebagai berikut:

\section{FGD (Focus Group Discussion) sebagai Instrumen Penyamaan Persepsi}

FGD dilakukan untuk dua tujuan yaitu memahami model co-management air minum yang selama ini dipraktekkan. Selain itu, membangun kesadaran akan pengelolaan air minum bersama-sama. FGD juga dimaksudkan mencari masukan-masukan dari pengurus HIPPAM level dusun tentang model pengelolaan air minum yang diharapkan ke depan.

Pada FGD HIPPAM di Dusun Pandan yang dihadiri pengurus HIPPAM dan perangkat Pemerintah Desa membahas tentang kelahiran HIPPAM dan pemenuhan kebutuhan air yang belum merata.Sekalipun telah diketahui penyelesaiannya, tetapi tetap menjadi kendala 
disebabkan persoalan anggaran.Selain itu, melalui refleksi bersama diketahui bahwa keorganisasian HIPPAM belum baik. Sementara itu pada FGD HIPPAM Dusun Ngujung dibahas kualitas air minum yang belum sesuai dengan harapan masyarakat. Selain itu, retribusi HIPPAM tidak pernah utuh dikarenakan masih banyak yang berhenti di Ketua RT. Untuk penyelesaian masalah ada masukan untuk mencari sumber air yang baru. Sedangkan, untuk persoalan retribusi dibutuhkan aturan main yang membolehkan Ketua HIPPAM untuk bertindak lebih tegas.

Dalam FGD Dusun Kajar didiskusikan sistem pengelolaan air minum yang dijalankan selama ini.Penarikan reftribusi berjalan dengan baik karena optimalisasi peran Ketua RW. Sementara itu persoalan yang masih dihadapi yakni satu tandon yang digunakan bersama dengan HIPPAM Dusun Pandan. Menariknya, hanya di FGD dusun ini, Kepala Desa Pandanrejo hadir, sehingga mendukung dikeluarkannya Peraturan Desa (Perdes) yang mengatur HIPPAM.Sedangkan FGD di Dusun Dadapan, didiskusikan tentang konsumen HIPPAM yang belum tertib sehingga mempengaruhi keuangan yang belum seperti diharapkan.Selain itu, HIPPAM di dusun ini masih berbentuk panitia, jadi belum sebagai kepengurusan.

Sekalipun tujuan utama FGD untuk pencarian data-data dan pendalaman persoalan, tetapi melalui FGD ini terbangun kesadaran arti pentingnya pengelolaan air minum berbasis pembelajaran sosial. Dari FGD ini akhirnya disepakati untuk menata organisasi lebih maju. Sebagai kebutuhan akan adanya satu HIPPAM pada level Desa Pandanrejo, maka semua aktor co-management desa menyetujui dibentuknya HIPPAM Desa Pandanrejo. Di samping itu, sepakat dengan adanya ketentuan/mekanisme organisasi semua HIPPAM dan peraturan desa (Perdes) yang mengatur pengelolaan air minum desa. Hal ini menunjukkan bahwa FGD pada level dusun pada tahapan mendefinisikan persoalan. Brown dan Timmer (2006) menyatakan bahwa terdapat empat tahapan pada pembelajaran sosial itu, yakni mendefinisikan persoalan, menyeting arah, implementasi \& melakukan tindakan serta evaluasi-revisi.

\section{Sarasehan Antaraktor Co-Management Desa}

Kegiatan sarasehan merupakan hasil evaluasi dan refleksi lanjutan peneliti, terutama ketika menemukan fenomena lapang yaitu tidak adanya koordinasi antarHIPPAM. Selama ini HIPPAM dusun berjalan sendiri-sendiri, sehingga pengelolaan swadaya belum membuka diskusi satu dengan lain, maka keadaan atau kondisi ini perlu dicairkan. Pengurus HIPPAM se-desa perlu bertemu bersama pelaku-pelaku pemerintahan desa demi menghasilkan keputusan penting. 
Dari kegiatan ini tumbuh sikap saling belajar, menyamakan persepsi, saling memahami dan peduli tentang kondisi air yang mulai memprihatinkan di Kota Batu. Peran peneliti lebih banyak menjembatani dengan menampung masukan-masukan dari pengurus HIPPAM, mantan pengurus HIPPAM dan pengurus lembaga-lembaga desa yang lain.

Peserta sarasehan berjumlah 18 orang, terdiri dari: Sekretaris desa, Ketua BPD, Ketua LPMD, Anggota-anggota BPD, mantan pengurus HIPPAM dan pengurus HIPPAM dusun. Perwakilan semua pihak memberikan masukan untuk bahan pembuatan mekanisme organisasi, peraturan desa dan format HIPPAM Desa Pandanrejo. Jika HIPPAM desa menjadi satu maka pelayanan akan semakin baik karena satu tujuan dan satu harapan. Untuk itu perlu dibuat peraturan yang mengatur semua HIPPAM. Dalam kaitan ini BPD bersedia menjadi pencetus, dimana akan merancang draft Perdes air, untuk kemudian kerja sama dengan Pemerintah Desa menjadikan peraturan desa. Sementara itu Ketua BPD meminta keterlibatan pemerintah desa dimana sebagai pihak yang menerbitkan produk hukum.

Dalam saresehan ini berkembang masukan-masukan tentang Perdes yang diharapkan ada ke depan. Sekalipun pembuatan perdes agak sulit mengingat mewadahi HIPPAM-HIPPAM dusun tetapi bisa dibuat asalkan tidak bertentangan dengan kepentingan umum. BPD diminta merumuskan masukan-masukan draft peraturan desa untuk pengelolaan air minum, meliputi:

1. Pengurus tingkat desa

2. Syarat-syarat dan hak/kewajiban pengurus

3. Masa jabatan

4. Larangan pengurus dan konsumen

5. Tarif air (rumah tangga dan non rumah tangga)

6. Sanksi dan bentuk-bentuknya

7. Kas digunakan untuk apa saja, dari mana sumbernya, pengelolaan dan pengalokasian.

Firmankira menyatakan bahwa pembelajaran sosial terdiri atas 5 ikatan (untaian yang teranyam), yaitu: orientasi dan berfikir sistem, refleksi, integrasi, kolaborasi dan negosiasi. Pembelajaran sosial bsia melalui pengalaman langsung, observasi pengalaman orang lain dan modeling (Marveled, Moleend \& Constant Dangbegnon, 1999). Demi untuk menambah keyakinan atas kebutuhan kebijakan baru pada pengelolaan air minum, peneliti melakukan survei untuk menangkap aspirasi, harapan dan keinginan-keinginan konsumen.Sampel berjumlah 300 orang, dimana dari Dusun Dadapan (45 responden), Dusun Ngujung (75 responden), Dusun Pandan (100 responden) dan Dusun Kajar (80 responden). Survei dilakukan selama 15 hari (20 September- 4 Oktober 2013) dengan hasil sebagai berikut: 
a. Pendapat responden tentang pengelolaan air minum oleh HIPPAM, yang menjawab bagus $266(89 \%)$ responden, sementara itu yang menjawab tidak bagus 34 (11\%) responden.

b. Pendapat responden tentang perlu/tidaknya aturan-aturan organisasi dalam HIPPAM, ada $232(77 \%)$ responden yang menjawab perlu, sedangkan yang menjawab tidak perlu 62 (21\%) dan tidak menjawab hanya $6(2 \%)$ responden.

c. Pendapat responden tentang perlu/tidaknya peraturan desa yang mengatur HIPPAM, ada $235(78 \%)$ responden yang menjawab perlu, sedangkan yang menjawab tidak 46 (16\%) dan tidak menjawab hanya $19(6 \%)$ responden.

Bisa disimpulkan bahwa konsumen HIPPAM semua dusun di Desa Pandanrejo mayoritas menginginkan pengaturan HIPPAM baik secara internal maupun eksternal (dalam relasi dengan Pemerintah Desa).Gambaran inilah yang mematangkan rencana penelitian ini berikutnya yakni melahirkan mekanisme organisasi dan Perdes yang mengatur pengelolaan air mimun di Desa Pandanrejo.

\section{FGD Aktor Co-Management Keseluruhan}

FGD ini selain bertujuan menggali persoalan-persoalan pada praktik co-management selama ini, juga sebagai forum untuk menyadarkan aktor-aktor untuk bekerja pada sebuah tim. Co-management selama ini dipraktikkan secara intensif hanya pada level desa saja, padahal pelaku co-management juga melibatkan level kota. Dengan demikian perlu dilakukan FGD dengan melibatkan pelaku-pelaku kota, seperti: Bagian Hukum Setda Kota Batu, Dinas Pengairan dan Binamarga, Dinas Cipta Karya dan Tata Ruang, BAPPEDA, Kantor Lingkungan Hidup, PDAM Kota Batu dan NGO (Non Governmental Organization).

Dari dinas-dinas pemerintah hadir 8 orang, sementara itu dari Pemerintahan Desa Pandanrejo hadir 16 orang, meliputi: kepala desa, sekretaris desa, kaur pemerintahan, Ketua BPD, Ketua LPMD, Bendahara LPMD, anggota-anggota BPD dan Ketua-Ketua HIPPAM seDesa Pandanrejo.

Persoalan-persoalan yang dibahas antara lain hubungan dinas-dinas dengan semua HIPPAM.HIPPAM Dusun Pandan mempertanyakan pengajuan bantuan yang jarang disetujui Dinas Pengairan dan Binamarga. Sementara itu, HIPPAM Dusun Ngujung mendapatkan masalah ketika mengurus perizinan pengambilan air. Masih dari HIPPAM Dusun Ngujung juga bertanya kepada KLH Kota Batu terkait uji air minum layak konsumsi. Kemudian, terkait pembuatan Perdes pengelolaan air, Kaur pemerintahan meminta masukan dari Bagian Hukum Setda Kota Batu. 
Selain itu, menariknya FGD juga membahas masalah "terpendam" antara Pemerintahan Desa Pandanrejo dengan PDAM Kota Batu.Selama ini, 3 HIPPAM di Desa Pandanrejo berdiri dengan sebelumnya melepaskan diri dari sebagai pelanggan PDAM Kota Batu.Ternyata, masih ada pipa-pipa PDAM di Desa Pandanrejo yang belum jelas statusnya.Karena itu, Kepala Desa dan Ketua BPD meminta supaya aset PDAM tersebut diberikan HIPPAM.Dari PDAM menyatakan bahwa persoalan itu bisa diselesaikan secara baik asal adanya komunikasi antarinstansi.

Dari FGD ini sebenarnya bisa dikatakan bahwa langkah awal pembelajaran sosial yaitu mempertemukan semua pihak dalam diskusi pelaku-pelaku co-management, baik dari desa dengan pelaku dari kota. Wollenberg, Eva dan kawan-kawan (2005) dan Wastl, Claudia Pahl \& Matt Hare (2004) menjelaskan bahwa pembelajaran sosial memfasilitasi penyelesaian masalah bersama dengan cara mendorong lahirnya kesadaran tentang tujuan dan persepsi tidak sama, memahami kompleksitas co-management, memahami kerja bersama dan mengkreasi baik hubungan formal maupun informal. Selain itu membangun persepsi tentang ketergantungan, kepercayaan dan saling menghargai.

Pada FGD yang melibatkan semua aktor co-management ini, pihak-pihak yang memiliki latar belakang berbeda berupaya saling memahami dan saling belajar atas persepsi masingmasing. Latar belakang pelaku yang berbeda akan membuat banyak perbedaan persepsi yang harus didamaikan. Dari lapangan, masing-masing pihak sama-sama belajar dengan saling memahami persepsi masing-masing.Persoalan-persoalan yang selama ini belum terkomunikasikan mampu dicari titik temunya. Demikian pula, baik antara aktor level desa maupun level kota membangun kebersamaan dan kepercayaan (trust).

\section{Kesimpulan}

Sekalipun co-management diyakini sebagai model pengelolaan sumber daya alam yang ideal disebabkan pertukaran sumber daya, pengurangan biaya dan resiko, mengatasi ketidakpercayaan, inefisiensi dan pencegahan konflik, tetapi sering masih ditemukan kelemahan yaitu jaringan sosial belum berperan secara efektif. Pembelajaran sosial mampu menutupi kelemahan ini sebab membuka kesediaan semua aktor untuk melakukan pembelajaran.

Pembelajaran sosial sudah ada pada aktor-aktor co-management karena kepemilikan pengetahuan lokal yang sudah dipraktekkan. Sekalipun demikian, dilapangan masih ditemukan kelemahan pada pembelajaran sosial tersebut, untuk itu diperlukan intervensi sosial, seperti: FGD dan sarasehan, dimana kedua forum ini sebagai sarana saling memahami, 
saling belajar atas persepsi masing-masing, memecahkan persoalan-persoalan yang selama ini belum terkomunikasikan, membangun kebersamaan dan kepercayaan (trust). Kemudian, agar FGD ini benar-benar menghasilkan keuntungan baik secara ekologis, ekonomis maupun sosial, maka praktik pembelajaran tidak boleh berhenti, tetapi harus dikembangkan secara terus menerus.

\section{Referensi}

Brown, David L \& Vanessa Timmer, 2006, Civil Society Actors as Catalysts for Transnational Social Learning, Voluntas: International Journal of Voluntary and Non Profit Organization, Vol. 17, No.1, March 2006

Gross, Matthias, Harald Heinrich (ed), 2010, Environmental Sociology: European Perspective and Interdisciplinary Challenges, Springer

Hanif, Hasrul, 2008, Mengembalikan Daulat Warga Pesisir, Partisipasi, Representasi dan Demokrasi di Aras Lokal, Yogyakarta: Pustaka Pelajar

Isyaku, Usman, 2011, Murtala Chindo, Mukhtar Ibrahim, 2011, Assesing Community based Janawi, 2013, Metodologi dan Pendekatan Pembelajaran, Yogyakarta: Ombak

Marveled, Moleend \& Constant Dangbegnon, 1999, Managing Natural Resources: A Social Learning Perspective, Agriculture and Human Value Volume 16: 267-280

Mc Conney, Pomeroy, Mahon, 2003, Guidelines for Coastal Resource co-management in the Carribean: Communicating The Concepts and Conditions that Favour Succes, CCA in association with CERMES and MRAG

Mc Fadden, Loraine, Sally Priest \& Colin Green, 2008, Introducing Social Learning: A Guide For Spicosa Scientists, London, Flood Hazard Research Centre, Middlesex University

Natural Resources Management at Lake Naivasha, Kenya dalam Jurnal Environment and Natural Research, Vol I, No. 1, December 2011

Olsson, P, Carl Folke, Vitor Galaz, Thomas Hahn dan Lisen Schultz, 2008, Enhancing the Fit through Adaptive Co-management: Creating and Maintaining Brdiging Functions for Matching Scales in the Kristianstands Vaterrnrike Biosphere Reserve, Sweden

Sekhar, Udaya Nagothu, 2006, Social Capital and Fisheries Management: The Case of Chilika Lake, India, Environment Management (2007) 39: 497-505

Sobirin, Menjaga Air Tetap Mengalir: Politik Air dalam Skema Industrialisasi Pati Selatan, dalam Prasetia Heru \& Bosman Batubara, 2010, Bencana Industri: Relasi Negara, Perusahaan dan Masyarakat Sipil 
Steyaert \& Jiggins, 2007, Governance of Complex Environmental Situation Through Social Learning: A Synthesis of SLIMs Lessons for Research, Policy and Practice

Susilo, Rachmad K Dwi, 2010, Co-management Air Minum untuk Kesejahteraan Masyarakat Sekitar, Yogyakarta: Samudra Biru

White, Foote William (editor), 1991, Participatory Action Research, Sage: California, London dan New Delhi

Wollenberg, Eva dan kawan-kawan (editor), 2005, Pembelajaran Sosial dalam Pengelolaan Hutan Komunitas Bogor: Pustaka LATIN kerja sama dengan CIFOR,

Wostl, Claudia Pahl \& Matt Hare, 2004, Processes of Social Learning in Integrated Resources Management, Journal of Community and Applied Social Psychology, 14 : 193-206 